\title{
Relationship Management : Lessons from Saptapadi - Indian Marriage Model
}

\author{
K.V. M. Varambally ${ }^{1} \&$ P. S. Aithal ${ }^{2}$ \\ ${ }^{1}$ Research Professor, College of Management \& Commerce, Srinivas University, \\ Mangalore- 575 001, India \\ E-mail: kvmvarampally@gmail.com \\ ${ }^{2}$ Professor, College of Management \& Commerce, Srinivas University, Mangalore - 575001 \\ ORCID: https://orcid.org/0000-0002-4691-8736; Email: psaithal@gamil.com
}

Area of the Paper: Business Management.

Type of the Paper: Research Paper.

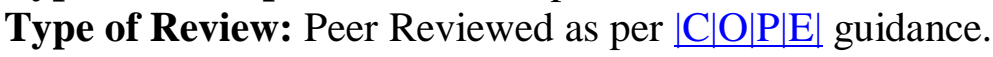

Indexed In: OpenAIRE.

DOI: http://doi.org/10.5281/zenodo.3596231.

Google Scholar Citation: IJCSBE.

\section{How to Cite this Paper:}

Varambally, K. V. M., \& Aithal, P. S. (2019).Relationship Management : Lessons from Saptapadi - Indian Marriage Model. International Journal of Case Studies in Business, IT, and Education (IJCSBE), 3(2), 105-110. DOI: http://doi.org/10.5281/zenodo.3596231.

International Journal of Case Studies in Business, IT and Education (IJCSBE)

A Refereed International Journal of Srinivas University, India.

IFSIJ Journal Impact Factor for 2019-20= 4.252

(C) With Authors.

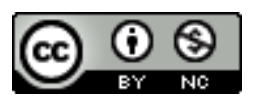

This work is licensed under a Creative Commons AttributionNon-Commercial 4.0 International License subject to proper citation to the publication source of the work.

Disclaimer: The scholarly papers as reviewed and published by the Srinivas Publications (S.P.), India are the views and opinions of their respective authors and are not the views or opinions of the S.P. The S.P. disclaims of any harm or loss caused due to the published content to any party. 


\title{
Relationship Management : Lessons from Saptapadi - Indian Marriage Model
}

\author{
K. V. M. Varambally ${ }^{1} \&$ P. S. Aithal ${ }^{2}$ \\ ${ }^{1}$ Research Professor, College of Management \& Commerce, Srinivas University, \\ Mangalore- 575 001, India \\ E-mail: kvmvarampally@gmail.com \\ ${ }^{2}$ Professor, College of Management \& Commerce, Srinivas University, Mangalore - 575001 \\ ORCID: https://orcid.org/0000-0002-4691-8736; Email: psaithal@gamil.com
}

\begin{abstract}
Relationship is important for an individual as well as to an organisation. Better relationship brings the people closer and strengthen the mutual concern and care. In a business organisation amicable relationship between employer and employee leads to its growth and development. This paper aims to highlight the relationship oath taken by bride and bridegroom in Hindu marriage and its relevance to business situations. Integrity mutual trust responsible behaviour, whole hearted participation would help the business organisation. It accelerates the organizations progress in a faster rate in the changing market environment so that the organization can improve its overall performance.
\end{abstract}

Keywords: Hindu marriage, Seven combined steps, Conducive environment, Social welfare, Organisational stability.

\section{INTRODUCTION :}

Relationship management is an important strategy in present business organizations to maintain a continuous level of engagement with all stakeholders including customers, suppliers, and collaborators. Managing relationships is an essential emotional infrastructure of organization and is an essential management skill that enables the organization to effectively lead the change required for organizational survival, sustainability, competency, and growth. Relationship management is a complicated issue for management professionals and depends on how people will respond to each other and how they'll work together in an interdependent organizational system. The competencies required to build and maintain the effective relationship between stakeholders as per contemporary management literature include : Inspiration, Influence, Develop, Initiate, change, Manage, conflict, and Establishing teams and collaboration [1]. But the essence of effective relationship management can be derived more effectively from the old Indian traditional marriage model called saptapadi. We know that marriage is a religious sacrament. It enables the young bride and bridegroom to enter their married life in the presence of relatives, friends, and elders. It is perceived that the blessings of elders during marriage functions enable the young couples to nurture their future smoothly with everlasting bondage between them [2-4].

In Hindu marriages especially among Brahmins, both bride and groom take seven oaths in front of holy fire in seven steps. This is known as "Saptapadi". The holy fire is the witness "Agni Sakshi" for the oaths taken by them. The responsibility of the priest who performs the marriage is not only to administer the oath but also explain to the bride and groom the meaning and implications of the oath and seven steps. For each step with oath, both the groom and bride have to go around the holy fire as per the guidance of the priest [5-8].

The Saptapadi oath covers role and responsibility of both the bride and groom in their entire married life. They not only accept each other in the presence of holy fire but also agree to maintain harmony, trust mutual concern and care towards property, family and live as responsible and respectful citizens in the community [9-10]. The lessons of Saptapadi oath can also be extended to the corporate world where employee-employer relationship prevails like many other management lessons which are also derived from Indian philosophy and traditions [11]. 


\section{OBJECTIVE AND MEHODOLOGY :}

The objective of the paper is to explain the relevance of "saptapadi" (seven steps) oath taken by bride and groom during the occasionof their marriage and its implication to business world. The paper is based on the conceptual analysis of the contents of oath taken by bride and groom, administered by the priest and management of such relationship by committed couples.

\section{SAPTAPADI STEPS AND MEANING :}

Saptapadi oath contains seven parts and is integrated with combined walk of seven steps to be performed by bride and groom. Each combined step has its own significance to manage future married life together.

Step One: “OM ESHA YEKAPADI BAVAH”, means the oath taken in the first step is to nourish each other. It is a promise of both bride and groom to show their responsibility of taking care of others in the life journey. Both have equal responsibility. If husband is the bread earner the wife has to take care of household activities in a responsible way. There is no under estimation of the work of anyone. The responsibilities of both husband and wife are of equal importance, then only family can move in the right direction. Here complex of superiority or subordinations does not arise because both are responsible and need to perform their tasks in the family journey. This relationship between husband and wife and their role and responsibilities can be extended to corporate world where employees employer relationship prevails.

To nourish the organisation both the employer and employee need to play their role appropriately. Employer needs to extend his affection towards employees and the employees in turn needs to extend their loyalty and integrity towards their organisation where they earn their livelihood. Ego and hateredness spoils the environment and work culture. Mutual harmony and trustworthiness among both the party enable the organisation to accelerate its development process.

Step Two : "OM URJE DWIPADIBHAVAH" the oath in second step is the determination towards progress and growth. In the journey of family life there is need for growth and further improvement in terms of financial strength of the family and capacity of the family to sustain in vibrant conditions. Hence the role of both husband and wife is to put efforts to enhance the stability of the family and also determine to grow and improve the base of the family. Both need to aim at future progress.

In an organisational setup both employee and employer need to put their heart and soul towards the success of their business. There is need for complete effort and whole hearted participation of both the party to usher the development process. They need to work efficiently and effectively to build the image of the organisation and bring stability in its position.

Step Three : OM RAJAS POSHAY TRIPADI BHAVAH” the third step in Saptapadi is pertaining to promise of both to preserve the wealth and property belonging to the family. The wealth or resources of the family should not be depleted or destroyed by the action of any one of them. To maintain standard of the family, preservation offamily resource plays an important role. Husband and wife need to pay attention to preserve or conserve the family resources. This helps them to lead a good life and also to show the way of living to their next generation.

In business situation it is the responsibility of both owners and employees to maintain the resources for sustainability and growth of business enterprise. Their action or inaction should not come in the way of the resource depletion. We can see in several instances the revolutionary workers destroy the business resources. Both the party need to understand their responsibility to keep up the fitness of business.

Step Four : “OM BHAYOBHVYAH CHATUSPADI BHAVAH” the fourth step is to serve each other with happiness and harmony. Providing needy service and care taking is the responsibility of both. While serving another person both of them need to perform their task happily with utmost care. Mutual understanding and clarity in purpose enable them to do their work joyfully with at most satisfaction. During ailment or sickness, the service of other person with affection and care is very much important then only both of them feel that they are integral part of family system with mutual binding relationship.

In the organisational climate it is the responsibility of both employees and employer to provide yeomen needy service during critical situation. Performing their task with at most care help the 
organisation to come out of crisis. There is no scope for showing vengeance or neglecting their work due to their prejudiced feeling. Both parties have to understand the problem of the organisation and need to pay attention to solve it whole heartedly.

Step Five : "OM PRAJA BHAYAH PANCHAPADI BHAVAH" The fifth step is related to the promise of both to take care of their children. They need to stick to the principle nurse the baby and protect the child and provide required guidance and support until the children become adult.

In a business set up it is the responsibility of the top management and also the bottom-line staff to see that their products are processed, manufactured and delivered to the customers in an acceptable way.

Step Six : “OM RUTU BHAYAH SHATPADI BHAVAH" In the sixth step both the groom and bride take the oath to be together forever in all seasons, in all situations of stress and difficulties. Be together during the situations of problem improve their love and affection and it helps them to face challenges in life. Both of them determine to maintain oneness throughout their life. There is no question of backing out or not willing to give company in a distress situation. Unity gives the strength during unfavourable situations.

In a business activity boom and recession is common. Here both the top management and shop floor workers need to maintain unity among themselves to absorb the shock given by market situation.

Step Seven : "OM ESHA SAKHA SAPTAPADI BHAVAH" The seventh and last step is pertaining to maintain ideal and everlasting friendship in thinking and acting. In physical relation (kaya) in interaction (Vacha) in thinking (manasa) they need to maintain purity as real friends. Both agree to maintain ideal relationship which will be an example to others. This brings happiness and harmony throughout their family life.

\section{MANAGEMENT LESSON ANALYSIS AND SUGGESTIONS :}

Today in marriage functions everything is done like a ritual. Both bride and groom are not clear about the relevance of Saptapadi. Understanding the relevance is very much necessary because divorce and separation after marriage and misunderstanding is common nowadays. Understanding the principles laid behind Saptapadi and its moral implications enable both bride and groom to discharge their roles and responsibilities in the family life. The bondage between them has ethical and moral implications. This is the responsibility of the elders to educate the young people to be clear about their duties and responsibilities in the family life, lack of which may break the relationship and cause problems in their family life. The managerial implications of seven steps oath taken in Hindu marriage rite for a manager in an organization for sustainable relationship management is depicted in table 1.

Table 1 : Managerial implications of seven steps of Saptapadi

\begin{tabular}{|c|c|l|l|}
\hline S. No. & Steps & Meaning of the oath & $\begin{array}{l}\text { Implications of Relational management in } \\
\text { organizations }\end{array}$ \\
\hline 1 & One & To nourish each other & $\begin{array}{l}\text { Mutual concern between employer and employee is } \\
\text { necessary for the healthy growth of an } \\
\text { organisation. Employer must exhibit his concern } \\
\text { towards employees and employees needs to show } \\
\text { their respect and loyalty to the organisation. }\end{array}$ \\
\hline 2 & Two & $\begin{array}{l}\text { Determination towards } \\
\text { lifelong progress and } \\
\text { growth }\end{array}$ & $\begin{array}{l}\text { Both employer and employee need to take part in } \\
\text { long term plans of the organisations. Both of them } \\
\text { need to provide input for futuristic plan of an } \\
\text { organisation. }\end{array}$ \\
\hline 3 & Three & $\begin{array}{l}\text { Promise of both to } \\
\text { preserve the wealth and } \\
\text { property belonging to the } \\
\text { family }\end{array}$ & $\begin{array}{l}\text { Employer and employee need to show their } \\
\text { concern and care towards resource conservations, } \\
\text { cost control and waste management. }\end{array}$ \\
\hline 4 & Four & $\begin{array}{l}\text { To serve each other with } \\
\text { happiness and harmony }\end{array}$ & $\begin{array}{l}\text { Cordial relationship must prevail and employee } \\
\text { employer relationship has to be amicable and a } \\
\text { conducive environment must be created by them. }\end{array}$ \\
\hline 5 & Five & The promise of both to & \begin{tabular}{l} 
To enhance the quality of products, quality of \\
\hline
\end{tabular}
\end{tabular}




\begin{tabular}{|c|c|l|l|}
\hline & take care of their children & $\begin{array}{l}\text { inventory management, both of them need to put } \\
\text { their efforts. }\end{array}$ \\
\hline 6 & Six & $\begin{array}{l}\text { Be together forever in all } \\
\text { seasons, in all situations } \\
\text { of stress and difficulties }\end{array}$ & $\begin{array}{l}\text { During good times and during bad times both of } \\
\text { them must work together as partners. }\end{array}$ \\
\hline 7 & Seven & $\begin{array}{l}\text { Maintain ideal and } \\
\text { everlasting friendship in } \\
\text { thinking and acting }\end{array}$ & $\begin{array}{l}\text { Both employee and employer have to build up a } \\
\text { good relationship so that individual growth and } \\
\text { Institutional growth must go together. This enables } \\
\text { long term binding and development of employees } \\
\text { as stake holders. Unity, Integrity and mutual } \\
\text { trust are key elements in an ideal relationship. }\end{array}$ \\
\hline
\end{tabular}

While applying this concept to business environment, it is both the top management and employee are responsible for survival and growth of the business. Both of them are like two wheels of a cart. Both the wheels need to be perfect for the mobility of the cart. The cart cannot move smoothly if one wheel is strong enough and the other one is weak. Unity, integrity, honesty, loyalty, harmony and mutual relationship are the necessary concepts for bringing solid foundation for business.

\section{CONCLUSION :}

The concept of saptapadi is relevant for family life which helps to keep up better relationship among husband and wife. Maintenance of cordial relationship among people create a conclusive environment in a community. Quality of living calls for better understanding and mutual cooperation. Ideal family helps to create ideal society and social welfare. In business activity it is the relationship between the management and working class which decides the future of the business.

\section{REFERENCES :}

[1] Lambert, D. M. (2010). Customer relationship management as a business process. Journal of Business \& Industrial Marketing, 25(1), 4-17.

[2] Roy, R. (2004). " Saptapadi"--the Seven Steps: A Study of the Urban Hindu Arranged Marriage in Selected Indian-English Fiction by Women Authors: a Thesis Submitted in Partial Fulfilment of the Requirements for the Degree of Doctor of Philosophy in the University of Canterbury (Doctoral dissertation, University of Canterbury).

[3] Menski, W. F. (1993). Legal pluralism in the Hindu marriage. Institutions and Ideologies: A SOAS South Asia Reader, (10), 148-164.

[4] Raizada, R. K. (2015). The Hindu Matrimonial Law. 016, 432-454. http://14.139.60.114:8080/jspui/bitstream/123456789/3234/1/050 1969 The\%20Hindu\%20Matrimon ial\%20Law.pdf. Retrieved on 28/10/2019.

[5] Anasthas, A. G. (2006). Inculturating the Marriage Rite. Marriage, 12(1), 64-76.

[6] Patyal, H. C., \&Patyal, H. C. (1976). The Saptapadi Rite. Bulletin of the Deccan College Research Institute, 35(3/4), 104-112.

[7] Gupta, N. S. (2016). Primitive traits in Hindu marriage rituals. pp. 20-45. http://ir.inflibnet.ac.in:8080/jspui/bitstream/10603/157613/3/03_content.pdf. $\quad$ Retrieved on 28/10/2019.

[8] Malhotra, A., \& Malhotra, R. (2001). Some perspectives on Indian family law. Int'l Surv. Fam. L., 115-119.

[9] Keith Bradford (1975). Marriage by proxy, Journal of Ethnic and Migration Studies, 4:2, 254-255. DOI :https://doi.org/10.1080/1369183X.1975.9975367.

[10] Francavilla, D. (2011). Interacting legal orders and child marriages in India. Am. UJ Gender Soc. Pol'y\& L., 19, 529-547. 
[11] Varambally, K. V. M., \& Aithal, P. S. (2019). Animal World and Living Behaviour - Managerial Implications. International Journal of Management, Technology, and Social Sciences (IJMTS), 4(2), 104-109. DOI: http://doi.org/10.5281/zenodo.3564958. 